\title{
REVITALISASI SISTEM PEMERINTAHAN DESA DALAM PERSPEKTIF UNDANG-UNDANG NO. 6 TAHUN 2014 TENTANG DESA DI PROVINSI SUMATERA BARAT
}

\author{
Donny Michael \\ Badan Penelitian dan Pengembangan Hukum dan HAM \\ Kementerian Hukum dan HAM RI \\ JI. HR. Rasuna Said Kav.4-5, Kuningan Jakarta Selatan 12940 \\ Email: dmsitumorang@yahoo.com
}

Tulisan Diterima: 18/03/2016 Direvisi: 27/04/2016 Disetujui: 14-07-2016

\begin{abstract}
Abstrak
Berangkat dari Nawa Cita ketiga yaitu "membangun Indonesia dari pinggiran dengan memperkuat daerah-daerah dan desa dalam kerangka Negara Kesatuan Republik Indonesia" dan kesadaran untuk melaksanakan amanat Undang-Undang Nomor 6 Tahun 2014 tentang Desa. Tujuan penelitian ini untuk mengetahui pengakuan hak atas asal usul masyarakat desa serta melihat peta keragaman kesiapan kelembagaan desa dan fisibilitas mengenai pengelolaan dana desa, dengan menggunakan metode kualitatif. Dari data lapangan dapat disimpulkan bahwa Undang-Undang No.6 Tahun 2014 tentang Desa berupaya mengkoreksi kesalahan-kesalahan Negara dalam mengatur desa dan masyarakat hukum adat. Undang-Undang desa ingin mengembalikan hak asal usul yang melekat pada desa adat untuk mengurus kehidupan masyarakat hukum adat dan pengurusan wilayah masyarakat hukum adatnya (hak ulayat). Negara perlu memberikan sarana dan prasarana kepada setiap lembaga adat agar lembaga adat dalam mengelola masyarakat adat serta adat istiadatnya dapat berjalan dengan baik. Untuk itu, perlu ada payung hukum untuk menampung keistimewaan desa adat dibeberapa daerah. Selain itu juga, perlu diatur secara khusus didalam peraturan perundang-undangan mengenai penetapan anggaran khusus terhadap lembaga-lembaga adat, sehingga lambat laun keberadaan lembaga adat ini tidak akan hilang.
\end{abstract}

Kata kunci: Revitalisasi, Pemerintahan Desa, Sumatera Barat.

\begin{abstract}
Based on the third Nawa Cita it is "to build Indonesia by strengthening areas and villages within the framework of The Unitary State of the Republic of Indonesia" and awareness to implement the Act No. 62014 about Village. The purpose of this research is to know the recognition of the origin of rural community rights and to look at the map of the diversity of Village institutional readiness and feasibility on the village funds management, by using the qualitative method. From the data the field we can conclude that the act of no. 6 year 2014 village about trying to emend state mistakes in regulating village and community adat law. The act of village want to restore the right of the origin of attached to customary village to take care of the lives of the customary law and management of the region of law community custom (unalienated rights). The state needs to give of facilities and infrastructure to every customary institutions that create a conducive customary in managing indigenous people as well as customary to take place. For that, there should be a legal framework for accommodate village customary privileges of several regions. It is also, needs to be regulated specifically in the legislation regarding the stipulation of a special budget against customary institutions, so which gradually customary the existence of this institution will be lost.
\end{abstract}

Keywords: Revitalization, Village Administration, West Sumatra 


\section{PENDAHULUAN}

\section{Latar Belakang}

Desa adalah bentuk pemerintahan formal terkecil dalam struktur pemerintahan di Indonesia. Sampai tahun 2016 ada sekitar 73.000 (tujuh puluh tiga ribu) Desa dan sekitar 8.000 (delapan ribu) kelurahan. ${ }^{1}$ Desa-desa tersebut dapat dibedakan antara desa biasa dan desa adat. Karena itu, ada dua konsep masyarakat berdasarkan klasifikasi desa itu, yaitu (i) masyarakat desa, dan (ii) masyarakat adat. Pelanggaran terhadap eksistensi dan identitas kultural masyarakat hukum adat, terjadi setelah diundangkan Undang-Undang No. 5 Tahun 1979 tentang Pemerintahan Desa, sewaktu seluruh struktur pemerintahan desa di Indonesia disamakan menurut model pemerintahan desa di pulau Jawa yang semata-semata bersifat teritorial, dan tidak mengakui masyarakat hukum adat. Akibatnya ${ }^{2}$ desa-desa teritorial genealogis, komunitas nomadik dan atau masyarakat hukum adat yang terdapat di luar pulau Jawa dalam kurun sejarah yang panjang, telah tereliminasi.

Perkembangan terakhir regulasi terhadap desa muncul berupa Undang-Undang No. 6 Tahun 2014 tentang Desa. Hal ini merupakan refleksi dari penghormatan terhadap hak-hak tradisional dan asal usul desa yang merupakan sistem politik yang berada pada tataran akar rumput (grassroot). Keberadaan Undang-Undang No. 6 Tahun2014 tentang Desa sebenarnya merupakan revitalisasi hak asal usul dan hak tradisional dari masyarakat desa (asli) setelah pemberlakuan UU No. 5 Tahun 1979 tentang Pemerintahan Desa. Meskipun demikian masih terdapat pandangan yang kontra saat disahkannya UU tersebut. Hal ini sebagaimana diungkapkan Ketua Lembaga Kerapatan Adat Alam Minangkabau (LKAAM)

1

Data ini dipakai dalam Penjelasan Umum UU Nomor 6 Tahun 2014 tentang Desa. Tambahan Lembaran Negara Republik Indonesia (TLN-RI) Nomor 5495. Menurut data Kementerian Dalam Negeri, jumlah desa di seluruh Indonesia tercatat 65.189 buah. Lihat www.kemendagri.go.id/media/ filemanager/2010/01/29/0/_/0._induk.kec.pdf; Dari sumber lain, tercatat pula bahwa jumlah desa di seluruh Indonesia sebanyak 76.546 desa. Sedangkan menurut data Statistik BPS 2008, jumlah desa di seluruh Indonesia ada 67.245 desa dan 7.893 kelurahan. Lihat www. sp.2010.bps.go.id/ files/ebook/Stat_Podes_Indonesia_2008.pdf.

2 Kesimpulan Lokakarya Nasional Inventarisasi dan Perlindungan Hak Masyarakat Hukum Adat, Jakarta, 14-15 Juni 2005
Sumatera Barat M Sayuti Dt. Rajo Penghulu yang berpandangan sebaliknya. Menurutnya, UU Desa tidak boleh diberlakukan Pemerintah. "Kami terkejut dengan pengesahan UU Desa, dan tentu kami sangat menentangnya. Jika UU Desa tersebut dijalankan, maka Negara tidak lagi menghormati kearifan lokal, Negara telah mencabik-cabik Bhinneka Tunggal Ika, Negara telah mengobrak-abrik NKRI". ${ }^{3}$

Untuk itu perlu pemahaman yang komprehensif tentang ragam desa dengan berbagai pendekatan yang dapat dilakukan. Isu-isu yang terkait dengan hal tersebut antara lain standar yang berlaku umum dalam mengoperasionalisasi hak-hak desa; penetapan desa sebagai desa (administratif) atau desa adat; realisasi pengakuan atas hak asal-usul yang melihat desa baik sebagai persekutuan sosial dan budaya; desa sebagai persekutuan hukum, politik, dan pemerintahan; dan desa sebagai persekutuan ekonomi (sebagai ekspresi dari penguasaan desa atas sumbersumber kehidupan yang menjadi ulayatnya); perpanjangan masa jabatan kepala desa menjadi enam tahun serta periode jabatan menjadi tiga periode; dan pengelolaan keuangan yang relatif besar di tingkat desa. ${ }^{4}$

\section{Rumusan Masalah}

Berdasarkan latar belakang yang telah diuraikan maka permasalahan dapat dirumuskan sebagai berikut: bagaimanakah pengakuan hak atas asal usul masyarakat desa khususnya Desa Nagari di Provinsi Sumatera Barat dalam pengaturan sistem pemerintahan menurut Undang-Undang Nomor 6 Tahun 2014 tentang Desa, dan bagaimanakah peta keragaman kesiapan kelembagaan desa dalam penerapan Undang-Undang Nomor 6 Tahun 2014 tentang Desa khususnya mengenai pengelolaan dana desa?

\section{Tujuan}

Tulisan ini setidaknya akan mengetahui pengakuan hak atas asal usul masyarakat desa dalam pengaturan sistem pemerintahan menurut Undang-Undang Nomor 6 Tahun 2014

\footnotetext{
3 http://www.academia.edu/5596371/Menimbang-nimbang_ Kemaslahatan UU Desa 2013 diakses pada 24 Maret 2014

$4 \quad$ Ibid.
} 
tentang Desa, serta untuk mengetahui peta keragaman kesiapan kelembagaan desa dan fisibilitas penerapan Undang-Undang Nomor 6 Tahun 2014 khususnya mengenai pengelolaan anggaran desa.

\section{Kerangka Pikir}

Pasal 18B ayat (2) Undang-Undang Dasar Negara Republik Indonesia Tahun 1945 Amandemen Kedua Tahun 2000.

Negara mengakui dan menghormati kesatuan-kesatuan masyarakat hukum adat beserta hak-hak tradisionalnya sepanjang masih hidup dan sesuai dengan perkembangan masyarakat dan prinsip Negara Kesatuan Republik Indonesia, yang diatur dalam Undang-Undang.

Pasal 28I ayat (3), (4) dan (5) UndangUndang Dasar Negara Republik Indonesia Tahun 1945 Amandemen Kedua Tahun 2000.

(3) Identitas budaya dan hak masyarakat tradisional dihormati selaras dengan perkembangan zaman dan peradaban.

(4) Perlindungan, pemajuan, penegakan, dan pemenuhan hak asasi manusia adalah tanggung jawab negara, terutama pemerintah.

(5) Untuk menegakkan dan melindungi hak asasi manusia sesuai dengan prinsip negara hukum yang demokratis, maka pelaksanaan hak asasi manusia dijamin, diatur, dan dituangkan dalam peraturan perundang-undangan.

Pasal 1 ayat (1) Kovenan Internasional Hak-hak Sipil dan Politik tertulis bahwa semua bangsa berhak untuk menentukan nasib sendiri. Berdasarkan hak tersebut mereka bebas untuk menentukan status politik mereka dan bebas untuk mengejar kemajuan ekonomi, sosial dan budaya mereka.

Pasal 25 huruf (a) dan (c) Kovenan Internasional Hak-hak Sipil dan Politik, Setiap warga negara harus mempunyai hak dan kesempatan, tanpa pembedaan apapun sebagaimana yang dimaksud dalam Pasal 2 dan tanpa pembatasan yang tidak layak, untuk:

a) Ikut serta dalam pelaksanaan urusan pemerintahan, baik secara langsung ataupun melalui wakil-wakil yang dipilih secara bebas;

c) Memperoleh akses pada pelayanan umum di negaranya atas dasar persamaan dalam arti umum.

Dari sudut pandang ketatanegaraan hubungan negara dan warga negara dapat dilihat dari aspek konstitusi. ${ }^{5}$ Konstitusi sebagaimana disebutkan merupakan aturan-aturan dasar yang dibentuk dalam mengatur hubungan antar negara dan warga negara. Konstitusi juga dapat dipahami sebagai bagian dari social contract (kontrak sosial) yang memuat aturan main dalam berbangsa dan bernegara. Lebih jelas, Sobernin Lohman menjelaskan bahwa dalam konstitusi harus memuat unsur-unsur sebagai berikut:

1. Konstitusi dipandang sebagai perwujudan perjanjian masyarakat (kontrak sosial), artinya bahwa konstitusi merupakan konklusi dari kesepakatan masyarakat untuk membina negara dan pemerintahan yang akan mengatur mereka;

2. Konstitusi sebagai piagam yang menjamin hak-hak asasi manusia dan warga negara sekaligus penentuan batas-batas hak dan kewajiban warga negara dan alat-alat pemerintahannya;

3. Konstitusisebagai forma regimenis yaitu kerangka bangunan pemerintahan.

\section{Kerangka Teori}

Teori Penetrasi Politik adalah sebuah kemampuan negara untuk menjangkau seluruh wilayah dan rakyat yang ada dalam yurisdiksinya sehingga wilayah dan rakyat dapat diatur dan dipersatukan menjadi sebuah entitas.

\section{Metodologi Penelitian}

Penelitian ini menggunakan pendekatan kualitatif (qualitative research design). Pendekatan ini digunakan untukmenggambarkan perubahan pengaturan sistem pemerintahan desa berdasarkan Undang-Undang Nomor 6 Tahun 2014 tentang Desa, mengetahui respon pemangku kepentingan (stakeholder) terhadap

5 Tim ICCE (Indonesian Center for Civic Education) UIN Jakarta, 2000, Demokrasi, Hak Asasi Manusia dan Masyarakat Madani, Jakarta: Prenada Media, hlm. 91-92. 
Undang-Undang Nomor 6 Tahun 2014 tentang Desa, dan mengindentifikasi langkah-langkah yang perlu dipersiapkan atas penerapan UndangUndang Nomor 6 Tahun 2014 tentang Desa.

Metode yang digunakan untuk pengumpulan data adalah melalui wawancara, dengan mengambil informan yang berasal dari kelompok pejabat pemerintah di tingkat provinsi/kabupaten/ kota, lembaga masyarakat adat/desa, dan akademisi, yang ditentukan dengan cara sengaja (purposive sampling).

\section{PEMBAHASAN}

\section{Karakteristik Desa di Sumatera Barat}

Secara etimologi, kata desa berasal dari bahasa Sansekerta, deca yang berarti tanah air, tanah asal, atau tanah kelahiran. Dari perspektif geografis, desa atau village diartikan sebagai "a groups of houses or shops in a country area, smaller than a town". Mengacu kepada UndangUndang No. 6 Tahun 2014 tentang Desa, Desa didefinisikan sebagai berikut:

Desa dan desa adat atau yang disebut dengan nama lain, selanjutnya disebut Desa, adalah kesatuan masyarakat hukum yang memiliki batas wilayah yang berwenang untuk mengatur dan mengurus urusan pemerintahan, kepentingan masyarakat setempat berdasarkan prakarsa masyarakat, hak asal usul, dan/atau hak tradisional yang diakui dan dihormati dalam sistem pemerintahan Negara Kesatuan Republik Indonesia. ${ }^{6}$

Pada dasarnya desa atau udik secara "universal" dapat didefinisikan, sebagai sebuah aglomerasi permukiman di area perdesaan (rural). Khusus di Indonesia, istilah desa adalah pembagian wilayah administratif di bawah kecamatan, dan biasanya dipimpin oleh seorang Kepala Desa. Secara struktural sebuah desa biasanya merupakan kumpulan dari beberapa unit pemukiman kecil, misalnya Jorong di Sumatera Barat. Pembentukan Nagari di Minangkabau Sumatera Barat lebih didominasi secara geneologis. Hal ini berbeda dengan dasar pembentukan desa di Jawa, Madura dan

6 UU Nomor 6 Tahun 2014 tentang Desa, Lembaran Negara Republik Indonesia Tahun 2014 Nomor 7
Bali, yang lebih menonjol adalah faktor teritorial (wilayah).

Nagari sebagai unit pemerintahan sudah dikenal sebelum Belanda menginjakkan kakinya di nusantara ini. Van Vollenhoven dalam bukunya "Staatsrechts Overzee" menggambarkan ketika Belanda datang ke Sumatera Barat bukanlah daratan yang kosong, tetapi sudah ada persekutuan hukum yang disebut dengan "landshappen" penuh penghuni dengan pola pemerintahan zelregerende landschappen yang ia sebut ada yang berbentuk niet monarchisch/ republikeinsch". ${ }^{7}$ Dalam bentuk asal (asli) nagari dahulu merupakan sebuah republik kecil yang disebut dengan kleine republikeins. Bentuk itulah yang ditegaskan oleh Mestika Zed (1996) menyerupai "polis" negara kota di Yunani Kuno. ${ }^{8}$

Secara historis pemerintahan nagari merupakan sebuah pemerintahan tradisional yang diperintah oleh penghulu-penghulu suku yang memiliki kewenangan yang sama derajatnya yang tergabung dalam sebuah kerapatan adat. Sistem Pemerintahan Nagari di wilayah Minangkabau diyakini telah diterapkan jauh sebelum berdirinya kerajaan Pagaruyung. Tetapi semuanya itu berubah semenjak dikeluarkannya Undang-undang Nomor 5 Tahun 1979 tentang Pemerintahan Desa yang telah menyeragamkan sistem pemerintahan terendah di seluruh Indonesia.

Semenjak tanggal 1 Agustus 1983, seluruh nagari-nagari yang ada di Sumatera Barat dileburkan menjadi pemerintahan desa. Jorong yang menjadi bagian nagari waktu itu langsung dijadikan desa, sehingga nagari dengan sendirinya menjadi hilang. Pemerintahan desa yang berasal dari budaya Jawa dipimpin oleh seorang Kepala Desa. Pada pemerintahan desa, desa atau kelurahan adalah bagian dari wilayah kecamatan. Dalam menjalankan hak, wewenang dan kewajiban pimpinan pemerintahan desa, Kepala Desa bertanggung jawab kepada pejabat yang berwenang mengangkat melalui Camat, dan memberikan keterangan pertanggungjawaban tersebut kepada Lembaga Musyawarah Desa (LMD).

RDH Koesoemahatmadja, Pengantar Kearah Sistem Pemerintahan Daerah di Indonesia, Alumni, Bandung, 1979.

8 Naskah Akademik "Rancangan Peraturan Daerah Provinsi Sumatera Barat Tentang Nagari", Pemerintah Provinsi Sumatera Barat, Padang, 2014 
Pemerintahan desa memang telah berjalan sejak tahun 1983 di seluruh Indonesia. Tetapi bagi kebanyakan daerah umumnya dan Sumatera Barat khususnya, ternyata pemerintahan desa telah menimbulkan berbagai dampak terhadap tatanan kehidupan masyarakat. Adapun dampak dihilangkannya Sistem Pemerintahan Nagari di Sumatera Barat adalah : 9

1. Jati diri masyarakat Minagkabau mengalami erosi. Pemahaman dan penghayatan falsafah adat Minagkabau Adat Basandi Syarak, Syarak Basandi Kitabullah, Syarak Mangato Adat Mamakai, Alam Takambang jadi Guru mengalami degradasi;

2. Anak nagari tidak lagi mempunyai kewenangan politis. Hubungan erat yang pernah terjalin antara pemerintah dengan anak nagari dan masyarakat adat menjadi semakin berkurang, bahkan hilang;

3. Hilangnya batas-batas nagari sehingga wilayah nagari terpecah. Pembentukan dan pemekaran desa menyebabkan hilangnya salah satu syarat adanya wilayah suatu nagari, yaitu mempunyai wilayah dengan batas-batas yang jelas;

4. Masyarakat kehilangan tokoh Angku Palo atau Wali Nagari. Fungsinya tidak dapat digantikan oleh Kepala Desa atau Lurah. Wali Nagari adalah tokoh kharismatik yang sangat dihormati dan menjadi panutan bagi anak nagari. Wali Nagari tidak hanya menguasai dan memahami seluk beluk pemerintahan nagari tetapi juga menguasai dan memahami adat istiadat serta taat beragama. Sedangkan kebanyakan dari Kepala Desa atau Lurah merupakan orang-orang muda yang kurang memahami adat istiadat setempat. Bahkan ada diantara mereka bukan berasal dari desa setempat;
5. Sistem Sentralistik yang diterapkan selama pemerintahan orde baru sangat mengurangi nilai-nilai luhur yang diwarisi sejak lama seperti gotongroyong dan sistem demokrasi;

6. Aspirasi anak nagari dalam pembangunan kehilangan wadah aslinya yaitu nagari;

7. Generasi muda Minang sudah banyak yang tidak mengetahui dan memahami tentang nagari, terutama mereka yang tinggal di kota;

8. Tungku Tigo Sajarangan dan Tali Tigo Sapilin terpinggirkan dan kehilangan fungsinya.

Pada masa lalu kewenangan nagari mencakup seluruh fungsi kekuasaan negara, yaitu: (1) kewenangan pemerintahan (executive); (2) kewenangan peradilan (judicative); (3) kewenangan peraturan dalam persekutuan (legislative); (4) kewenangan atas hak persekutuan tanah (beheer atas tanah). ${ }^{10}$ Beberapa kebijakan dikeluarkan setelah kemerdekaan yang mengatur nagari. Kebijakan yang kontroversi namun mendapat dukungan dari Pemerintah Pusat adalah ketika diterbitkan Peraturan Daerah Tingkat I Sumatera Barat Nomor 7 Tahun 1981 tentang Pemerintahan Desa di Sumatera Barat sebagai pelaksanaan Undang-Undang Nomor 5 Tahun 1979. Kebijakan pemerintah dalam melakukan uniformitas bentuk pemerintahan terendah di seluruh Indonesia dengan sebutan Desa.

Dengan berlakunya Undang-Undang No.22 Tahun 1999 tentang Pemerintahan Daerah telah terjadi perubahan paradigma penyelenggaraan pemerintah baru, dari sentralistik ke desentralistik. Untuk merespon semangat desentralisasi di Sumatera Barat, maka telah ditetapkan Peraturan Daerah No.9 Tahun 2000 tentang Pokok-pokok Pemerintahan Nagari, dan terakhir nagari diatur dengan Peraturan Daerah No.2 Tahun 2007 tentang Pokok-pokok Pemerintahan Nagari. Menurut Yulizal Yunus Dt. Rajo Bagindo dalam tulisannya:

"Dahulu ketika pemerintahan desa melaksanakan Undang-Undang No. 5 Tahun

9 http://digilib.uin-suka.ac.id/16964/2/11340065_bab-i_ivatau-v_daftar-pustaka.pdf

10 ibid 
1979 dan Peraturan Daerah Sumbar No.13 Tahun 1983, nagari tidak pecah dan kelembagaan adat tetap eksis, sekarang di era otonomi daerah melaksanakan Undang-Undang No.22 Tahun 1999 diganti dengan Undang-Undang No. 32 Tahun 2004 dan Undang-Undang No. 08 Tahun 2005 dan Perda No.09 Tahun 2000 direvisi Perda No.02 Tahun 2007, justru nagari lama menjadi pecah dan dibagi dalam beberapa nagari disebut dengan istilah pemekaran". ${ }^{11}$

Hal tersebut diatas, juga dikuatkan oleh salah satu Kepala Bidang di Bappeda Provinsi Sumatera Barat bahwa:

"Di Sumatera Barat jumlah nagari asli adalah 543 nagari, dan seiring waktu ada perkembangan kabupaten sehingga jumlah nagari bertambah menjadi 800 nagari (sehingga konteks ini menunjukkan bahwa adanya peningkatan jumlah nagari dalam konteks pemerintahan, bukan nagari dalam konteks satu-kesatuan hukum adat). Dalam perkembangannya, Sumatera Barat dengan bertambahnya jumlah penduduk, luas wilayah, letak geografis maka terjadi pemekaran pemerintahan nagari, sehingga perda yang baru ini akan menambahkan jumlah nagari dalam konteks kesatuan hukum adat. Hal inilah yang menjadi penolakan oleh Lembaga Kerapatan Alam Adat Minangkabau (LKAAM), karena menurut LKAAM nagari merupakan satukesatuan hukum adat yang tidak dapat dipisah-pisahkan. Nagari (adat) dipimpin oleh kepala Kerapatan Adat Nagari (KAN) sedangkan Nagari (pemerintahan) dipimpin oleh wali Nagari dan dipilih oleh masyarakat dengan aparatus didalamnya."12

Kewenangan yang begitu besar dimiliki Nagari pada masa lampau, saat ini memang terasa simbolik. Kerinduan akan kewenangan dan peran itu semakin dirasakan dalam kehidupan modern. Karena itu perlu revitalisasi fungsi dan kewenangan Nagari melalui penetapan Nagari disamping sebagai masyarakat hukum adat juga sebagai unit penyelenggara pemerintahan

11 https://wawasanislam.wordpress.com/2009/03/06/ pemahaman-tentang-nagari/

12 Wawancara dengan salah seorang kepala bidang di Bappeda, tanggal 9 September 2015 terendahatau terdepan. Dengan diundangkannya Undang-Undang No. 6 Tahun 2014 tentang Desa, eksistensi Nagari kembali menarik perhatian semua komponen masyarakat di Sumatera Barat, baik kalangan adat, pemerintahan maupun akademisi. Momentum ini memberi peluang bagi masyarakatSumateraBaratuntukmenatakembali sistem pemerintahan terendah berdasarkan adat Salingka Nagari. Sejak diberlakukannya otonomi daerah, istilah Desa dapat disebut dengan nama lain, misalnya di Sumatera Barat disebut dengan Nagari. Begitu pula segala istilah dan institusi di Desa dapat disebut dengan nama lain sesuai dengan karakteristik adat istiadat Desa tersebut. Hal ini merupakan salah satu pengakuan dan penghormatan Negara terhadap asal usul dan adat istiadat setempat.

Kekhasan ini tentu diikuti dengan keragaman sistem yang berbasis budaya lokal, indigenous sistem tersebut harus dihormati keberadaanya. Penyeragaman sistem yang pernah dilakukan di era orde baru hampir membunuh sistem berbagai budaya yang kaya akan kearifan. Era reformasi merupakan era desentralisasi, era kebangkitan untuk pengembalian sistem nilai lokal dan pengakuannya sehingga dapat bersinergi dengan sistem formal yang dibangun dalam kerangka Negara Kesatuan Republik Indonesia yang Bhineka Tunggal Ika.

Pengakuan ini diundangkan dalam Undang-Undang Nomor 6 Tahun 2014 tentang Desa. Akan tetapi setiap pasal yang terdapat dalam Undang Undang Nomor 6 Tahun 2014 tentang Desa tersebut terutama yang berkaitan dengan penjelasan identitas desa, kewenangan dan instrumen sistem yang dibangun dalam undang-undang ini merupakan legalisasi bentuk pemerintahan desa lokal dengan berbagai kearifannya. Ada beberapa hal yang masih perlu disempurnakan, sehingga Undang-Undang Desa ini tidak berlaku "pukul rata" bagi seluruh wilayah NKRI. Eksistensi desa adat di Provinsi Sumatera Barat merupakan benang sejarah yang tidak bisa dihapuskan. Nilai lokal sebenarnya berkontribusi banyak terhadap nilai formal dalam pemerintahan desa, seperti halnya keberadaan Nagari.

Ada beberapa aspek permasalahan yang menyebabkan Pemerintahan Nagari sejak reformasi sampai sekarang hanya sekedar nama saja "pemerintahan Nagari" sedangkan isinya sebetulnya adalah "desa", antara lain adalah a. 
Aspek fundamental, kewenangan Nagari yang terlalu terfokus pada administrasi pemerintahan sehingga belum menyentuh persoalan adat dan budaya, serta belum menyatunya penyelenggaraan pemerintahan dengan adat. b. Aspek Struktural, masih terjadinya dualisme kepemimpinan di Nagari, susunan pemerintahan Nagarimasihmengacukepadapolapemerintahan desa. c. Aspek Institusional, belum jelasnya kedudukan nagari dalam konteks NKRI, apakah dibawah kecamatan atau kabupaten/kota, belum bersinergi peran lembaga bentukan dengan lembaga asli nagari dalam penyelenggaraan pemerintahan nagari.

Berdasarkan permasalahan diatas itulah menurut informasi yang diperoleh dari informan (Kepala Biro Hukum Pemerintah Provinsi Sumatera Barat), dinyatakan bahwa saat ini sedang disusun Rancangan Peraturan Daerah (Raperda) tentang Nagari. ${ }^{13}$ Dengan adanya peraturan daerah yang mengatur khusus tentang Nagari akan menjadi pijakan dasar bagi Nagari untuk menjalankan pemerintahan, pembangunan dan pembinaan kemasyarakatan Nagari. ${ }^{14}$ Pilihan penamaan Nagari menggantikan Desa dengan pertimbangan bahwa masyarakat Minang menganggap istilah Nagari lebih memiliki keeratan dibandingkan Desa. Hal ini dikarenakan perubahan Desa menjadi Nagari hanya mengganti nama saja sedangkan isinya tetap merupakan pemerintahan desa sebelumnya. ${ }^{15}$

\section{A. Pengakuan Hak Atas Asal Usul}

Sampai saat ini (pertengahan tahun 2015), bentuk pemerintahan di Sumatera Barat masih beraneka ragam, yaitu Nagari, desa, kelurahan. Hal ini dikarenakan penyelenggaraan pemerintahan di Propinsi Sumatera Barat sejak Orde Baru tidak memberikan peluang kekuasaan terhadap Nagari sebagai kesatuan masyarakat hukum adat, dan memisahkan konstruksi fungsi pemerintahan dengan adat sehingga memberikan kemunduran terhadap kelestarian nilai-nilai adat, budaya Minangkabau. Menurut Kepala Badan Pemberdayaan Masyarakat Propinsi Sumatera Barat, Nagari ini sudah ada sebelum kemerdekaan Republik Indonesia,

13 Wawancara dengan Biro Hukum Pemerintah Provinsi Sumatera Barat, tanggal 8 September 2015

14 ibid

15 Wawancara dengan Biro Pemerintahan Pemerintah Provinsi Sumatera Barat, tanggal 8 September 2015 dengan jumlah 543 Nagari. Kemudian munculnya Undang-Undang No. 5 Tahun 1979, Sumatera Barat mempunyai desa 800 desa. Setelah itu Undang-Undang No. 22 Tahun 1999 tentang Pemerintahan Daerah, jumlah Nagari yang ada di Sumatera Barat kembali menjadi 543 Nagari. Keunikan Nagari di Sumatera Barat adalah tiaptiap Nagari yang ada di Sumatera Barat satu dengan yang lainnya berbeda adat dan istiadat yang tidak bisa diintervensi. ${ }^{16}$

Hal tersebut diatas, juga dikuatkan dari pendapat Kepala Biro Hukum Pemprov Sumatera Barat, bahwa:

"Sebelum UU No.5 Tahun 1979, Sumatera Barat dikenal dengan nama Nagari. Dibawah Nagari dikenal dengan nama Korong/Jorong. Korong/jorong ini disamakan seperti desa yang ada di Pulau Jawa. Kemudian ketika UU No. 5 Tahun 1979 berlaku, bentuk unit pemerintahan terendah di seluruh Indonesia disamakan (desa di kabupaten, lurah di Kota), dan di Sumatera Barat status Jorong diganti menjadi desa, tidak membentuk desa baru. Yang menjadi persoalan adalah desa yang ada hanya mengatur pemerintahan, tidak mengatur adat istiadat. Kemudian dibentuklah perda yang berisi bahwa nagari merupakan satu kesatuan masyarakat hukum adat akan diatur dalam Perda No.12 Tahun 1983 tentang Nagari. Dimana Nagari sebagai satu kesatuan hukum adat masyarakat hukum adat dikepalai oleh ketua Kerabatan Adat Nagari (KAN), yang tugasnya menyangkut mengurus sako dan pusako. Tetapi dikarenakan KAN ini tidak ada peraturan yang mengatur, sekarang ini KAN mulai tergeser/lemah kedudukannya. Hal ini dapat dilihat misalnya dalam acara perkawinan, tidak ada keharusan perkawinan itu harus melewati KAN." 17

Di dalam Pasal 109 Undang-Undang No.6 Tahun 2014 tentang Desa, kewenangan provinsi hanya untuk mengatur kelembagaan, lama dan orangnya. Yang menjadi persoalan adalah

16 Wawancara dengan Kepala Badan Pemberdayaan Masyarakat Propinsi Sumatera Barat, tanggal 9 September 2015

17 Wawancara dengan Kepala Biro Hukum Pemerintahan Provinsi Sumatera Barat 
keinginan dari provinsi ketika dibentuk peraturan daerah yang mengatur tentang Nagari terlalu kecil, Desa/nagari yang berada di Sumatera Barat harus memilih antara Desa sebagai desa administrasi atau sebagai desa adat. Sedangkan tugas dan fungsi antara keduanya sangat berbeda. Desa/nagari mengatur administrasi sedangkan desa adat mempunyai tusinya adalah mengatur sako dan pusako, adat istiadat dan tidak mengatur terkait adminstrasi pemerintahan. Untuk itulah jika diharuskan memilih inilah yang bertentangan dengan konsep adat "indak lapuak dek paneh, indak lapuak dek hujan" artinya "tidak akan lapuk di timpa matahari. takkan lapuk di timpa hujan". Yang terjadi sekarang, jika disuruh memilih desa adat maka nagari yang ada tidak akan mau lagi bergabung menjadi Desa adat.

Untuk itu, jika melihat permasalahan diatas, penyelenggaraan Pemerintahan Nagari haruslah tetap diselenggarakan berdasarkan adat salingka nagari. Disamping sebagai unit kesatuan masyarakat hukum adat, Nagari juga merupakan bagian dari Negara Kesatuan Republik Indonesia. Karena itu penyelenggaraan Pemerintahan Nagari harus dapat diintegrasikan statusnya sebagai masyarakat hukum adat dan sebagai bagian dari negara. Dengan demikian tidak ada lagi pemisahan antara urusan adat dan urusan administrasi pemerintahan di Nagari, seperti sejak adanya pemberlakuan UndangUndang No.5 Tahun 1979.

Berbicara kewenangan Desa, pada awal hingga pertengahan tahun 2015 , terlihat jelas bahwa adanya tarik menarik kewenangan antara Kementerian Dalam Negeri dengan Kementerian Desa, Pembangunan Daerah Tertinggal dan Transmigrasi terkait persoalan desa. Hal ini dapat dilihat bahwa tata kelola desa berada dalam dua pilar kewenangan yang bersifat hirarkis. Pertama, kewenangan di bidang pemerintahan berada di pilar kendali Kementerian Dalam Negeri. Kedua, kewenangan di bidang pembangunan desa dan kawasan perdesaan di bawah naungan Kementerian Desa, Pembangunan Daerah Tertinggal dan Transmigrasi. Kedua pilar tersebut saling berebut kendali terhadap desa, dan kondisi ini tentu sangat "mengganggu" kewenangan yang bersifat rekognisi yang dimiliki desa.

Di dalam Komentar Umum 12 International Covenant On Civil And Political Rights (ICCPR), Pasal (1) jelas menyatakan bahwa adanya pengakuan semua orang memiliki hak untuk menentukan nasibnya sendiri. Hak untuk menentukan nasib sendiri menjadi penting karena pada dasarnya hak ini merupakan kondisi yang esensial bagi penjaminan dan pelaksanaan yang efektif dari hak asasi manusia individual serta bagi pemajuan dan penguatan hak-hak tersebut.

Selain itu, rumusan pada Pasal 18 B ayat (2) Undang-Undang Dasar 1945 dapat menjelaskan bahwa:

(a) Negara mengakui keberadaan kesatuan masyarakat hukum adat memang sudah ada sebelum Negara Kesatuan Republik Indonesia didirikan dan Undang-Undang Dasar 1945 disahkan;

(b) Keberadaan kesatuan masyarakat hukum adat yang diakui itu terbukti masih hidup sampai sekarang;

(c) Pengakuan itu dapat berubah dinamis mengikuti perkembangan masyarakat dalam arti perkembangan zaman di mana perasaan kemanusiaan dan tingkat peradaban tumbuh dan berkembang sedemikian rupa sehingga pengakuan atas keberadaan kesatuan masyarakat hukum adat beserta hak-hak tradisionalnya itu juga harus disesuaikan dengan kebutuhan menurut ruang dan waktunya yang dinamis itu;

(d) Pengakuan itu juga tidak boleh bertentangan dengan prinsip dan kepentingan Negara Kesatuan Republik Indonesia, misalnya, di daerah perbatasan jangan sampai pengakuan ini dapat berdampak negatif kepada semangat persatuan bangsa dan integritas wilayah NKRI karena wilayah hukum adat yang bersangkutan melampuai batas wilayah hukum teritorial NKRI; dan

(e) Syarat dan prosedur pengakuan terhadap kesatuan masyarakat hukum adat beserta hak-hak tradisionalnya itu harus diatur dengan UU ataupun dalam pelbagai UU lain yang terkait.

Dalam konteks status politik yang tertera pada Kovenan Internasional Hak-Hak Sipil dan Politik, Undang-Undang No.6 Tahun 2014 tentang Desa telah mengakomodir terutama pada Pasal 13, yaitu: (1) Pemilihan Kepala 
Desa dilaksanakan secara serentak di seluruh wilayah Kabupaten/Kota. (2) Pemerintahan Daerah Kabupaten/Kota menetapkan kebijakan pelaksanaan pemilihan Kepala Desa secara serentak sebagaimana dimaksud pada ayat (1) dengan Peraturan Daerah Kabupaten/Kota. (3) Ketentuan lebih lanjut mengenai tata cara pemilihan Kepala Desa serentak sebagaimana dimaksud pada ayat (1) dan ayat (2) diatur dengan atau berdasarkan Peraturan Pemerintah. Selain itu juga pengaturan pemilihan Kepala Desa juga diatur didalam pada Pasal 34, antara lain ayat (1) Kepala Desa dipilih langsung oleh penduduk Desa. (2) Pemilihan Kepala Desa bersifat langsung, umum, bebas, rahasia, jujur, dan adil.

Di Pemerintahan Nagari, Nagari dipimpin oleh wali nagari. Dahulu, dalam menjalankan pemerintahannya Wali Nagari dibantu oleh beberapa Wali Jorong, tetapi di era sekarang ini dibantu oleh Sekretaris Nagari (setnag) dan beberapa pegawai negeri sipil (PNS) yang jumlahnya bergantung dengan kebutuhan pemerintahan nagari tersebut. Wali Nagari dipilih oleh Anak Nagari (penduduk nagari) secara demokratis dengan pemilihan langsung untuk masa jabatan 6 tahun dan kemudian dapat dipilih kembali untuk satu kali masa jabatan berikutnya. Biasanya yang dipilih menjadi Wali Nagari adalah orang yang dianggap paling menguasai tentang semua aspek kehidupan dalam budaya Minangkabau, sehingga Wali Nagari tersebut mampu menjawab semua persoalan yang dihadapi Anak Nagari. Pemerintahan Nagari (administratif) berada di bawah kecamatan yang merupakan bagian dari perangkat daerah kabupaten. Sedangkan nagari (adat) bukan merupakan bagian dari perangkat daerah dan berbeda dengan kelurahan, nagari (adat) memiliki hak mengatur wilayahnya yang lebih luas.

Jika merujuk pada definisi Undang-Undang No.6 Tahun 2014 tentang Desa, kewenangan berdasarkan Hak Asal Usul adalah hak yang merupakan warisan yang masih hidup dan prakarsa Desa atau prakarsa masyarakat Desa sesuai dengan perkembangan kehidupan masyarakat. Artinya bahwa kewenangan tersebut merupakan kewenangan yang dimiliki desa, bukan karena pemberian dari pemerintah pusat, melainkan kewenangan yang bersifat otonom hasil pemetaan terhadap riwayat desa tersebut.
Hal ini tentu saja berbeda dengan kewenangan lokal berskala Desa, yaitu kewenangan untuk mengaturdan mengurus kepentingan masyarakat Desa yang telah dijalankan oleh Desa atau mampu dan efektif dijalankan oleh Desa atau yang muncul karena perkembangan Desa dan prakarsa masyarakat Desa. Konsep kewenangan ini didasari pada prinsip desentralisasi, delegasi, dan dekonsentrasi.

Selain mengatur Hak untuk menentukan nasib sendiri di dalam Pasal 1 Kovenan Internasional Hak Sipil dan Politik juga mengatur tentang status Sumber Daya Alam, dalam hal ini aset desa. Dalam menjalankan pemerintahan, pembangunan dan pemberdayaan masyarakat, Nagari membutuhkan kekayaan sebagai sumber pendapatan. Kekayaan Nagari yang berasal dari hak atas asal usul ditetapkan sebagai kekayaan Nagari.

Undang-Undang Nomor 6 Tahun 2014 tentang Desa juga telah diatur tentang Pendapatan Asli Desa yaitu pada Pasal 72, Pendapatan Asli Desa bersumber dari:

a. Pendapatan asli Desa terdiri atas hasil usaha, hasil aset, swadaya dan partisipasi, gotong royong, dan lain-lain pendapatan asli Desa;

b. Alokasi Anggaran Pendapatan dan Belanja Negara;

c. Bagian dari hasil pajak daerah dan retribusi daerah Kabupaten/Kota;

d. Alokasi dana Desa yang merupakan bagian dari dana perimbangan yang diterima Kabupaten/Kota;

e. Bantuan keuangan dari Anggaran Pendapatan dan Belanja Daerah Provinsi dan Anggaran Pendapatan dan Belanja Daerah Kabupaten/Kota;

f. Hibah dan sumbangan yang tidak mengikat dari pihak ketiga; dan

g. lain-lain pendapatan Desa yang sah.

Alokasi Anggaran Pendapatan dan Belanja Negara yang dimaksud didalam Ayat (2) bersumber dari Belanja Pusat dengan mengefektifkan program yang berbasis Desa secara merata dan berkeadilan. Pendapatan Asli Desa dapat juga bersumber pada bagian hasil pajak daerah dan retribusi daerah Kabupaten/ 
Kota paling sedikit 10\% (sepuluh perseratus) dari pajak dan retribusi daerah.

Tetapi dalam prakteknya masih dirasakan berbeda oleh Kerapatan Adat Nagari, misalnya saja pernyataan dari Ketua KAN ${ }^{18}$ :

"Kami tokoh-tokoh adat di Sumatera Barat merasa bahwa pemerintah pusat dan daerah tidak memperhatikan KAN, padahal menurut hukum adat Sumatera Barat, tanah Sumatera Barat ini milik ninik mamak, dan Negara hanya mengatur saja.

Dahulu, KAN mengatur 12 desa/nagari terkait dengan kekayaan desa. dan semuanya itu diatur didalam perda. Dahulu nagari adalah kesatuan masyarakat hukum adat dan sekarang dibentuk lagi pemerintah nagari yang diketuai oleh wali nagari. Dan pada sekarang ini pemerintahan nagari terjadi pemekaran, sehingga kami tidak bisa lagi menikmati kekayaan ninik mamak/ kekayaan nagari sebagai satu kesatuan masyarakat hukum adat. Yang seharusnya pemerintahan mengatur administrasi nagari bukan harta kekayaan ninik mamak".

Dari kedua unsur di dalam Pasal (1) Kovenan Internasional Hak-Hak Sipil dan Politik telah diakomodir dan diatur didalam UndangUndang No. 6 Tahun 2014 tentang Desa. Hal ini menunjukkan bahwa, Undang-Undang No. 6 Tahun 2014 tentang Desa merupakan lompatan besar adanya pengakuan kedaulatan desa. Kebijakan ini sangat progresif, karena membuka akses dan relasi antara negara dan masyarakat desa. Dimana selama ini relasi tersebut sangat timpang dan bersifat subordinat, sehingga melumpuhkan kreativitas dan inovasi desa dalam membangun dirinya dan masyarakatnya.

Melalui Undang-Undang No. 6 Tahun 2014 tentang Desa, khususnya Peraturan Menteri Desa, Pembangunan Daerah Tertinggal dan Transmigrasi Nomor 1 Tahun 2015, Negara mengakui adanya Kewenangan Desa. Dimana secara eksplisit dijelaskan bahwa ruang lingkup Kewenangan Berdasarkan Hak Asal Usul Desa meliputi: sistem organisasi perangkat Desa; sistem organisasi masyarakat adat; pembinaan kelembagaan masyarakat; pembinaan lembaga dan hukum adat; pengelolaan tanah kas Desa; pengelolaan tanah Desa atau tanah hak milik Desa yang menggunakan sebutan setempat; pengelolaan tanah bengkok; pengelolaan tanah pecatu; pengelolaan tanah titisara; dan pengembangan peran masyarakat Desa.

Di dalam Bab XA Undang-Undang Dasar 1945 tentang Hak Asasi Manusia memperkuat pengakuan terhadap hak-hak yang melekat kepada 'kesatuan masyarakat hukum adat', 'masyarakat adat', atau 'desa atau disebut dengan nama lain'. Pasal 28I, menyebutkan bahwa "Identitas budaya dan hak masyarakat tradisional dihormati selaras dengan perkembangan zaman". Dan di dalam tujuan Undang-Undang No. 6 Tahun 2014 tentang Desa telah memperjelas Kedudukan Desa dalam struktur ketatanegaraan Republik Indonesia, dimana desa bukanlah merupakan sub-ordinat atau bagian dari Kabupaten/Kota melainkan satuan penyelenggara pemerintahan, sama halnya dengan Kabupaten/Kota.

Dalam masa transisi seperti saat ini perlu disadari bahwa ruh Undang-Undang Desa yang utama adalah "azas rekognisi" terhadap sistem pemerintahan yang asli. Keberadaaan Desa yang dibentuk berdasarkan Undang-Undang Desa (disebut Desa Dinas) mendampingi Desa Adat merupakan langkah kompromis yang bijaksana secara politis dalam perkembangan dinamika kehidupan bernegara yang merujuk kepada kebijakan rezim yang berkuasa dalam kurun waktu tersebut. Artinya formasi Desa Dinas dan Desa Nagari efektif dan operasional dalam payung hukum Undang-Undang No. 5 Tahun 1979 tentang Pemerintahan Desa. Dengan berlakunya Undang-Undang Desa yang memuat Asas Rekognisi sebenarnya keberadaan desa dinas bisa dihapuskan, dengan memunculkan pengakuan keberadaan sistem pemerintahan asli. Hal ini dapat menghilangkan konflik kepentingan sebagaimana yang dikeluhkan oleh para tokoh masyarakat adat. Hal itu timbul karena kewajiban register atas identitas desa seolah-olah di "klaim" oleh Desa Dinas.

Desa tidak hanya sekedar Pemerintahan Desa. oleh karenanya, kebijakan dan regulasi tentang desa harus lebih dari sekedar 'pemerintahan desa' itu. Kebijakan dimaksud haruslah mengarah pada realisasi pengakuan atas hak asal-usul yang melihat desa baik sebagai 
persekutuan sosial dan budaya, desa sebagai persekutuan hukum, politik, dan pemerintahan; dan desa sebagai persekutuan ekonomi (sebagai ekspresi dari penguasaan desa atas sumbersumber kehidupan yang menjadi ulayatnya).

Dengan simpul pemikiran yang demikian itu kita ingin merevitalisasi desa sebagai 'modal sosial' dalam menyongsong masa depan yang (bakal) tidak mudah itu. Baik karena faktor-faktor lokal, nasional, dan global. Selain itu, kebijakan baru bertujuan juga untuk mengkonsolidasi kembali sistem tenurial 'yang kadung amburadul' dan 'menyingkarkan hak-hak masyarakat adat' melalui pengakuan hak-hak asali desa sebagai dasar bagi 'pembaruan desa' dalam hal ini 'reforma agraria', sebagaimana telah diamanatkan dalam TAP MPR IX/2001.

Dengan demikian seolah-olah menegasikan Asas Rekognisi yang dimiliki oleh Desa Adat Nagari. Kekhawatiran dengan hilangnya Desa Dinas yang berakibat pada menghilangnya fungsi pelayanan publik yang dilakukan Desa Dinas, dapat dialihkan pada jajaran sistem pemerintahan setingkat diatasnya, yaitu Kelurahan/Kecamatan. Dengan demikian yang di register pada Kementerian Dalam Negeri adalah eksistensi Desa Adat Nagari. Kesemuanya merupakan bagian dari implementasi amanat dalam Undang-Undang Desa.

\section{B. Peta Keragaman Kesiapan Desa}

Berbicara kesiapan Desa dapat dilihat dari tiga aspek yang mempengaruhi kesiapan desa dalam mengimplementasikan Undang-Undang Nomor 6 Tahun 2014 tentang Desa, yaitu: aspek kelembagaan desa, aspek sumber daya manusia, dan aspek pengelolaan anggaran.

\section{Aspek Kelembagaan Desa}

Nagari merupakan kesatuan masyarakat hukum adat dalam daerah yang terdiri dari beberapa suku yang tergabung dalam Kerapatan Adat Nagari (KAN), mempunyai wilayah tertentu batas-batasnya, mempunyai harta kekayaan sendiri serta berhak mengatur dan mengurus rumah tangganya sendiri. Dalam mengatur kehidupan bernagari, masyarakat mensinergikan antara nilai agama dan nilai adat (syarak mangato adat mamakai), adat basandi syarak-syarak basandi kitabullah.

Walaupun terdapat desa administratif yang mempunyai wilayah yang sama dengan desa adat seperti nagari di Sumatera Barat, tetap saja terdapat dualisme sistem pemerintahan desa antara desa administratif yang dijalankan wali nagari dengan desa adat yang dijalankan Kerapatan Adat Nagari (KAN). Dualisme kelembagaan desa melahirkan konflik kewenangan untuk menjalankan hak asal usul terutama terkait pengurusan wilayah adat (hak ulayat). Hal tersebut berakibat pada lemahnya vitalitas nagari (desa adat) dalam mengekspresikan hak asal usulnya. Di sisi lain, penguasaan sumber daya alam masih ditangan pusat. Pemerintah pusat masih mendominasi kekuasannnya atas tanah, hutan dan sumber daya alam lainnya. Tanah-tanah adat (ulayat) masih terbagi-bagi oleh sektor pengurusan sumber daya alam oleh pemerintah.

Dari aspek kelembagaan, dapat dianalisa bahwa telah terjadi kekurangan sosialisasi serta sinergitas yang dilakukan oleh pemerintah daerah terhadap pelaksanaan Undang-Undang Nomor 6 Tahun 2014 tentang Desa. Dimana Undang-Undang Desa merupakan perangkat regulasi yang menempatkan Desa sebagai bagian dari entitas strategis untuk membangun kemandirian NKRI dari dalam serta pengakuan (rekognisi) atas keberagaman desa pada urutan terdepan. Dengan azas subsidaritas, desa memiliki kewenangan untuk mendefinisikan diri, memetakan apa permasalahan, mengidentifikasi potensi hingga mengambil keputusan kebijakan untuk mengurus rumah tangganya sesuai dengan kewenangan berdasarkan hak asal usul dan kewenangan desa berskala lokal. Lain dari pada itu untuk mendukung realisasi kewenangan desa membangun Negara Republik Indonesia mulai dari desa.

\section{Aspek Sumber Daya Manusia}

Dari aspek Sumber Daya Manusia, dapat dianalisa bahwa kurangnya Political will dari pemerintah daerah dalam mempersiapkan sumber daya manusia yang memadai untuk implementasi Undang-Undang Desa. Selain itu juga, menurut Kepala Badan Pemberdayaan Masyarakat, menyatakan bahwa kendala dalam mengimplementasi UU desa adalah susahnya mencari kepala desa yang masih berumur muda, kondisi di Sumatera Barat sekarang ini berumur 44 tahun. Selain itu juga belum ada juklak dan juknis untuk pengaturan anggaran desa. Untuk itu perlu ditingkatkan kembali skill 
atau kemampuan tiap-tiap aparatur Pemerintah Daerah dan Pemerintahan Desa terhadap substansi Undang-Undang Desa, dengan cara memberikan pelatihan atau penyuluhan kepada setiap aparatur pemerintahan daerah maupun aparatur desa. Dalam pendampingan masyarakat desa, perlu dilibatkan kembali PNPM Mandiri yang pernah ada, sehingga dalam mengelola program-program serta pertanggungjawaban anggaran dapat terlaksana dengan baik.

\section{Aspek Pengelolaan Anggaran}

Menurut Ketua Kerabatan Adat Nagari Lubuk Alung, ${ }^{19}$ dengan dikeluarkannya UU Desa ini adalah :

"Dahulu kabupaten Lubuk alung mendapatkan dana sebesar 400jt/tahun. Dan sekarang mendapatkan dana tambahan sebesar 353jt. Kendala yang dihadapi adalah penggunaan dana dikarenakan tidak ada juklak dan juknis dalam penggunaan anggaran, sehingga kami terlambat dalam penyerapan anggaran dana tersebut. Dari segi manfaat penambahan dana, kami dapat meningkatkan honor aparatur desa, yang dahulu honor tersebut masih dibawah UMR. Sebelum adanya UU desa, honor/gaji yang diterima oleh Kepala Nagari sebesar 2,3 juta/bulan yang dibayarkan pertiga bulan. Gaji untuk kaur sebesar 850rb, kepala Korong 600rb, yang semuanya itu juga sama diterima pertiga bulan. Di Sumatera Barat, tidak ada dana tambahan untuk gaji dari PAD. Tetapi untuk wali Nagari diberikan oleh pemerintah propinsi dana tambahan gaji sebesar $1 \mathrm{jt} /$ bulan. Setelah UU Desa ini, sudah ditetapkan oleh Bupati bahwa ada penambahan dana untuk gaji aparatur desa/ nagari. Misalnya kaur yang sebelumnya mendapat 850rb sekarang menjadi 1,6 jt. Wali nagari yang sebelumnya mendapat gaji 2,3 menjadi 2,9 jt/bulan.

Kemudian dalam pelaksanaan pengelolaan dana desa di Kabupaten Lubuk Alung belum ada pendamping yang ditunjuk untuk memberikan pengarahan dalam pengelolaan anggaran. Jadi sampai saat ini uang dana

19 Wawancara dengan Ketua KAN Lubuk Alung, tanggal 9 September 2015 tersebut belum bisa digunakan. Dana desa yang diterima oleh wali Nagari sebesar 750jt digunakan untuk: 229jt untuk penghasilan tetap; 15 jt untuk Lembaga BAMUS; $5 \mathrm{Jt}$ untuk Lembaga KAN (setahun); 3 jt untuk Lembaga Pemberdayaan Masyarakat (LPM); 1 juta untuk Lembaga pengelolaan Kekayaan nagari; 3 jt untuk lembaga lain; 5 jt untukPKK; Danayang lainnya diperuntukkan Infrastruktur dan pengembangan SDM, selain pembangunan kantor.

Dari dana yang diterima oleh KAN sebesar 5 juta/setahun, sedangkan anggota KAN berjumlah 125 orang/kaum. Semenjak UU Desa diterbitkan tidak ada lagi pungutan restibusi atau badan usaha milik desa."

Dari hasil temuan lapangan, dapat dianalisa bahwa perlunya peningkatan kemampuan aparatur desa dalam mengelola keuangan yang ada, dikhawatirkan, bila salah mengelola, akan menjadibumerangbagiaparatdesabersangkutan. Belum juga sempurna tahun pertama (2015) pelaksanaan kebijakan Dana Desa, Komisi Pemberantasan Korupsi merilis hasil studinya tentang pengelolaan keuangan desa yang kurang lebih menyimpulkan adanya ancaman praktik korupsi di hampir setiap tikungan tahapan proses pembangunan desa. Di tahap perencanaan titik rawannya berupa potensi pembajakan elit (elite capture) dan ketidaksesuaian penggunaan anggaran sesuai dengan aturannya yaitu $70 \%$ untuk pembangunan dan 30\% untuk biaya operasional desa. Pada tahapan pelaksanaan program/kegiatan pembangunan titik rawannya berupa Nepotisme, tidak adanya transparansi pembelanjaan anggaran hingga penyimpangan anggaran belanja.

Dari ketiga aspek tersebut di atas, menunjukkan bahwa masih kurangnya kesiapan pemerintahan desa dalam menciptakan tata pemerintahan yang berwawasan ke depan (visi strategis). Selain itu juga, untuk menciptakan pemerintahan desa yang baik perlu mendorong partisipasimasyarakatturutikutsertadalamproses perumusan dan/atau pengambilan keputusan atas kebijakan publik yang diperuntukkan bagi masyarakat, sehingga keterlibatan masyarakat sangat diperlukan pada setiap pengambilan kebijakan yang menyangkut masyarakat luas, serta pemerintah daerah haruslah cepat tanggap 
(responsive) terhadap perubahan situasi/kondisi mengakomodasi aspirasi masyarakat, serta mengambil prakarsa untuk mengatasi berbagai masalah yang dihadapi masyarakat desa. Dalam mengawal dana desa perlu adanya Tim monitoring independen yang terdiri dari berbagai kalangan, bisa akademisi atau lembaga independen lainya yang menjadi saraf sensorik pengawasan bagi kementerian desa. Lembaga pengawalan dan avokasi bisa diambil dari kalangan kampus atau lembaga independen lainya, dan untuk pendampingan hukum kanwil hukum dan HAM untuk kembantu teknik penyusunan peraturan perundang-undangan desa.

\section{PENUTUP}

\section{Kesimpulan}

Dari penjelasan semua di atas, UndangUndang No.6 Tahun 2014 tentang Desa telah mengakomodir pengakuan masyarakat hukum adat sebagai subjek hukum dalam sistem pemerintahan, yaitu menetapkan unit sosial masyarakat hukum adat seperti nagari di Sumatera Barat sebagai badan hukum publik. Selain menjalankan tugas kewenangan berdasarkan hak asal usul diatas, desa adat juga menjalankan kewenangan yang dilimpahkan pemerintah pusat dan daerah. Sehingga desa adat adalah perpaduan unit sosial masyarakat adat dengan unit pemerintahan.

Jika dilihat dari kewenangannya, kewenangan desa adat secara hukum lebih kuat dibandingkan pengaturan desa dalam undangundang Pemda. Sifat kewenangan desa dalam Undang-Undang Pemda adalah delegatif, yaitu menjalankan kewenangan Pemda oleh desa, sedangkan dalam UU Desa bersifat atributif, yaitu menjalankan kewenangan berdasarkan UU secara langsung sebagai perwujudan pelaksanaan UUD 1945, khususnya pasal 18 dan $18 \mathrm{~B}$ ayat 2 . Konsekuensi hukumnya adalah desa adat mempunyai kewenangan yang kuat dalam menjalankan hak asal usulnya yang dijamin oleh undnag-undang.

\section{Saran}

1. Perlu memberikan sarana dan prasarana kepada setiap lembaga adat agar lembaga adat dalam mengelola masyarakat adat serta adat istiadatnya dapat berjalan dengan baik. Untuk itu, perlu ada payung hukum untuk menampung keistimewaan desa adat dibeberapa daerah.

2. Perlu menyusun Petunjuk Pelaksanaan (Juklak) dan Petunjuk Teknis (Juknis) dalam penggunaan dana desa, agar sesuai dengan akidah hukum yang berlaku.

\section{DAFTAR PUSTAKA}

\section{Buku}

Koesoemahatmadja, RDH, Pengantar Kearah Sistem Pemerintahan Daerah di Indonesia, Alumni, Bandung, 1979.

Lokakarya Nasional Inventarisasi dan Perlindungan Hak Masyarakat Hukum Adat, Jakarta, 14-15 Juni 2005

Naskah Akademik "Rancangan Peraturan Daerah Provinsi Sumatera Barat Tentang Nagari", Pemerintah Provinsi Sumatera Barat, Padang, 2014

Tim ICCE (Indonesian Center for Civic Education) UIN Jakarta, "Demokrasi, HakAsasi Manusia dan Masyarakat Madani", Jakarta: Prenada Media, 2000

\section{Peraturan Perundang-undangan:}

UU Dasar Tahun 1945 (Amandemen 1 - 4)

UU Nomor 32 Tahun 2004 tentang Pemerintahan Daerah

UU Nomor 33 Tahun 2004 tentang Perimbangan Keuangan Pusat dan Daerah

UU Republik Indonesia Nomor 12 Tahun 2008 tentang Perubahan Kedua Atas UU Nomor 32 Tahun 2004 tentang Pemerintahan Daerah

UU Nomor 6 Tahun 2014 tentang Desa, Lembaran Negara Republik Indonesia Tahun 2014 Nomor 7

\section{Website}

w w w. ke mendagri.go.id/media/ filemanager/2010/01/29/0/_/0._induk.kec. pdf;

www.sp.2010.bps.go.id/files/ebook/Stat_Podes_ Indonesia_2008.pdf. 
www.academia.edu/5596371/Menimbangnimbang_Kemaslahatan_UU_Desa_2013. www.academia.edu/7874934/4_BAB_II_ KAJIAN_TEORI?

http://digilib.uin-suka.ac.id/16964/2/11340065_ bab-i_iv-atau-v_daftar-pustaka.pdf

\section{Wawancara}

Kepala bidang di Bappeda, Biro Hukum Pemerintah Provinsi, Biro Pemerintahan Pemerintah Provinsi, Kepala Badan Pemberdayaan Masyarakat Propinsi, Kepala Biro Hukum Pemerintahan Provinsi, Ketua KAN Datuk Suharman, Ketua KAN Lubuk Alung, 

